Available online at https://jurnal.stmikroyal.ac.id/index.php/jurdimas

\title{
RANCANGAN MODEL DIGITALISASI PASAR TRADISIONAL PASAR RARE ANGON DI DESA GUNAKSA
}

\author{
I Kadek Arta Wiguna ${ }^{1 *}$, I Komang Agus Ariana ${ }^{1}$ \\ ${ }^{1}$ Universitas Pendidikan Nasional \\ Email: *arta060599@gmail.com
}

\begin{abstract}
The increasing cases of covid-19 have an impact on the economy in Indonesia, especially on micro, small and medium enterprises (MSMEs). local communities who during this pandemic experienced a decline in income. Shoppers are starting to rarely come to the market and shop in person because of their fear of contracting Covid-19 and avoiding crowds that have been advised by the government. The digitalization of traditional people's markets is needed to improve the economy and reduce the spread of the covid-19 virus. The results of interviews with traders show the lack of sales at Rare Angon Market because few people know about the market. the method used by distributing questionnaires to find out in detail the existing problems. From these problems, a solution is needed to bridge between traders and buyers, this solution is in the form of digitizing the Rare Angon market by developing an application called "Rare Angon App" where the application is used for buying and selling interactions by traders and buyers. So that sales in the Rare Angon market can increase.
\end{abstract}

Keywords: E-commerce; traditional market; information technology

\begin{abstract}
Abstrak: Meningkatnya kasus covid-19 berdampak pada perekonomian di Indonesia terutama pada usaha mikro kecil meneengah (UMKM) hal ini dapat dilihat dari pasar-pasar rakyat di Bali yaitu Pasar Rare Angon yang berlokasi di desa Gunaksa, kecamatan Dawan kabupaten Klungkung dengan mayoritas pedangannya adalah warga didaerah setempat yang dimasa pandemi ini mengalami penurunan pendapatan. Para pembeli mulai jarang datang ke pasar dan berlanja secara langsung karena ketakutan mereka tertular covid-19 dan menghindari kerumunan yang sudah dihimbau oleh pemerintah. Diperlukannya digitalisasi pasar rakyat yang bersifat tradisional untuk meningkatkan perekonomian dan mengurangi penyebaran virus covid19. Hasil wawancara dengan pedagang menunjukkan minimnya penjualan di Pasar Rare Angon karena masih sedikit masyarakat yang tau pasar tersebut. metode yang digunakan dengan penyebaran kuesioner untuk mengetahui secara detail permasalahan yang ada. Dari permasalahan tersebut diperlukannya solusi untuk untuk menjembatanni antara pedagang dan pembeli, solusi ini berupa digitalisasi pasar Rare Angon ini dengan membuatkan aplikasi yang diberi nama "Rare Angon App" dimana aplikasi tersebut digunakan untuk interakasi jual beli oleh pedagang dan pembeli. Sehingga penjualan dipasar Rare Angon bisa mengalami peningkatan.
\end{abstract}

Kata kunci: E-commerce; pasar tradisional; teknologi informasi 
Available online at https://jurnal.stmikroyal.ac.id/index.php/jurdimas

\section{PENDAHULUAN}

Perkembangann dari zaman ke zaman tentu saja mengalami banyak perubahan seperti halnya pusat kegiatan masyarakat yang bersifat komersil atau yang sering disebut dengan pasar. Zaman sebelum adanya mata uang masyarakat melakukukan transaksi dengan metode barter yaitu dengan menukar barang satu dengan barang lainnya, sampai akhirnya munculnya mata uang membuat perubahan yang dulunya menukar antar barang ke menukar barang dengan uang (Bastian \& Yusuf, 2019). Pasar merupakan tempat interaksinya penjual dan pembeli, pasar dikategorikan menjadi dua yaitu pasar tradisional dan pasar modern (Masyhuri \& Utomo, 2017). Pasar tradisional merupakan tempat berkumpulnya penjual dengan menjual berbagai dagangannya dengan cara konvensional, berinteraksi langsung antara penjual dan pembeli dengan harga yang tidak tetap bisa dilakukan tawar menawar (Ariyani \& Nurcahyono, 2014). Sedangkan pasar modern tidak jauh beda dengan pasar tradisional hanya saja harga yang ditentkan oleh penjaul bersifat tetap tidak dapat di negosiasi, sehingga barang yang dijual sudah diberi label harga (Santosa, Suharjo, \& Sumiyarsih, 2020), Salah satu implementaasi pasar modern adalah e-commerce. E-commerce merupakan sebuah pasar yang berjalan dengan menggunakan sistem informasi sebagai medianya yang memanfaatkan teknologi internet. Dimana e-commerce ini pedagang dan pembeli bertansakasi tidak bertatapmuka langsung melainkan menggunakan platform aplikasi sebagai media transaksinya (Sigalingging \& Sitepu, 2020).

\begin{tabular}{lrr}
\multicolumn{1}{c}{ Desa } & Gunaksa & terletak di \\
kecamatan & Dawan, & kabupaten \\
Klungkung, provinsi Bali dengan luas
\end{tabular}

wilayah 683,006 Ha Dengan jumlah penduduk 6126 jiwa. Desa Gunaksa terdiri dari 7 banjar yaitu Banjar Patus, Banjar Bandung, Banjar Tengah, Banjar Nyamping, Banjar Babung, Banjar Buayang dan Banjar Kebon (Arta, 2021b). Desa Gunaksa baru baru ini memiliki pasar baru yang diberi nama "Pasar Rare Angon" yang memiliki 49 blok dan terletak di ujung desa, pasar ini dibuat untuk meningkatkan perekonomian didesa Gunaksa yang dimana penjual berasal dari desa Gunaksa dan target pembeli yaitu masyarakat desa Gunaksa dan sekitar (Arta, 2021a). Pasar ini dibuka pada tanggal 18 Januari 2021 dan sampai saat ini masih sepi pengunjung, salah satu penjual di pasar rare angon mengatakan pendapatan mereka perhari berjualan rata-rata $25 \mathrm{rb}$ sampai 35rb. Hal ini dikarenakan tempat pasar yang di ujung desa, desa Gunaksa telah memiliki pasar yang sudah berjalan sebelumnya dan ketakutan masyarakat tertular covid-19. Dari data Informasi \& Siaga COVID-19 Pemerintah kabupaten Klungkung tercatat sebanyak 50 orang yang tertular covid-19 di desa Gunaksa (Wirya, 2021). Hal ini mengakibatkan enggannya masyarakat desa Gunaksa untuk keluar rumah karna angka yang tertular covid-19 semakin hari semakin mengalami peningkatan.

Untuk meningkatkan penjualan di pasar rare angon di desa Gunksa serta memudahkan masyarakat untuk belanja tanpa perlu keluar rumah ini yang dimana dari jumlah penduduk di desa Gunaksa yang cukup banyak maka diperlukannya sentuhan teknologi informasi dengan melakukan digitalisasi pasar tradisional ini dengan konsep jual beli barang dengan sistem online seperti e-commerce dimana sistem ini dikelola oleh desa (Sudirman, 2020). 
Adapun tujuan dilakukan penelitiani ini yaitu untuk meningkatkan minat belanja di pasar rare angon yang akan dibuatkan rancangan digitalisasi dan meningkatkan perekonomian di desa Gunaksa melalui Pasar Rare Angon, yaitu berupa prototype aplikasi mobile yang nantinya bisa diaplikasikan saat pembuatan aplikasi.

\section{METODE}

Metode yang digunakan dalam memecahkan masalah ini mencangkup beberapa tahapan, yaitu:

Observasi mengenai keadaan pasar Rare Angon di desa Gunaksa dan pendataan untuk mengidentifikasi masalah Hal yang dilaksanakan pertama kali yaitu mengunjungi langsung lokasi pasar lama dan pasar Rare Angon untuk melihat situasi dan kondisi pasar desa Gunaksa pada tanggal 6 Februari 2021.

Tahapan wawancara, melakukan wawancara terhadap beberapa pedagang dan pembeli yang sedang berada di pasar Rare Angon. Dari hasil wawancara yang di dapatkan yaitu tingkat penjualan di pasar ini cukup rendah dan sedikit pengunjung, maka dari itu untuk mendapatkan data yang falid maka saya melakukan penyebaran kuisoner ke para pedagang melalui media google form.

Melakukan penyebaran kuesoner ke pedagang di pasar Rare Angon. Kuesoner ini disebar untuk mengetahui seberapa perlunya digitalisasi pasar Rare Angon untuk meningkatkan penjualan.

\section{PEMBAHASAN}

Berdasarkan hasil observasi yang dilakukan pada saat ke pasar desa Gunaksa terdapat perbedaan pasar lama dengan pasar Rare Angon desa Gunaksa, dimana pasar lama lebih banyak pengunjungnya karena masyarakat sudah terbiasa berbelanja disana dan sudah mengetahui tempat tempat pedagang yang akan dibeli barangnya, dibandingkan dengan pasar Rare Angon desa Gunaksa dikarenakan tempatnya yang di ujung desa. Selain tempatnya di ujung desa pasar Rare Angon juga belum banyak yang tau apa saja yang dijual disana sehingga sedikit masyarakat untuk berbelanja disana.

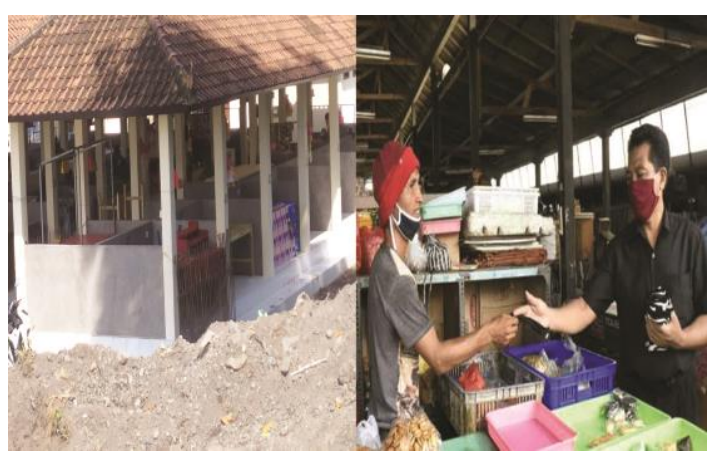

Gambar 1. Kondisi Pasar Rare Angon

Setelah melakukan observasi tahap selanjutnya melakukan wawancara terhadap beberapa pedangang di pasar Rare Angon secara langsung dan melalui media whatsapp. Berdasarkan hasil wawancara yang dilakukan pendapatan masyarakat yang berjualan di pasar rareangon bisa dibilang sangat sedikit. Menurut salah satu pedagang di pasar Rare Angon rata-rata hasil penjuala mereka perhari hanya 25 sampai 35 ribu perhari dan kadang tidak dapat penjualan sama sekali. Dari wawancara itu tadi maka untuk mengetahui lebih lanjut kondisi pasar Rare Angon secara detail pendapatan serta perlunya digitalisasi, maka tahap selanjutnya yaitu menyebar kuesioner ke pedagang di pasar Rare Angon. Dari hasil penyebaran kuesioner yang mengisi yaitu 40 responden dari 49 
Available online at https://jurnal.stmikroyal.ac.id/index.php/jurdimas

pedagang di pasar Rare Angon, usia para pedagang mulai dari usia 26 tahun sampai 39 tahun dan 40 tahun sampai 54 tahun. Barang yang dijual di pasar Rare Angon mulai dari sayuran, buah buahan, makanan, hingga produk hasil bumi lainnya dengan mayoritas yang dijual yaitu buah buahan. Dengan pendapatan para pedagang dibawah 50 ribu perhari dan ada juga yang mendapatkan penghasilan dibawah 25 ribu. Dilihat dari hasil kuisoner pengetahuan para pedagang tentang teknologi cukup tinggi, hal ini dapat dilihat dari pemahaman mereka terhadap internet yaitu $80 \%$ dari yang mengisi kuesioner. Para pedagang di pasar memiliki kebiasaan meng-gunakan smartphone, hal ini terlihat dari hasil penyebaran kuesoner yang sudah terisi yaitu $57,5 \%$ yang sangat sering menggunkan smartphone $35 \%$ yang sering menggunakan smartphone dan 7,5\% yang jarang menggunkan smartphone. Serta pemahaman pedagang untuk penjualan secara online cukup tinggi dilihat dari hasil kuesoner yang menunjukkan 15\% sangat paham, $60 \%$ paham, $20 \%$ kurang paham dan 5\% yang tidak paham Sehingga menurut per-tanyaan terakhir kuesoner yaitu setuju atau tidaknya jika diterapkan digitalisasi pasar Rare Angon para pedagang bisa mengaplikasikannya. Model pasar digital yang saya tawarkan yaitu penjual dan pembeli berinteraksi melalui suatu aplikasi yang diberi nama Rare Angon App, model aplikasi ini dirancang menggunakan kerangka Unified Modeling Language (UML) yang sederhana yaitu dengan menggunakan use case diagram.

Pada gambar 2 terlihat pemilik usaha atau penjual dapat mengelola katalog yang berisi benda dan stok yang tersedia. Sedangkan pada gambar 3 dan 4 terlihat pengelola pesanan saling terkoneksi dengan yang mengelola pem- bayaran, maka dari itu e-commerce belum terintegrari dengan pengiriman dan system strasing barang.

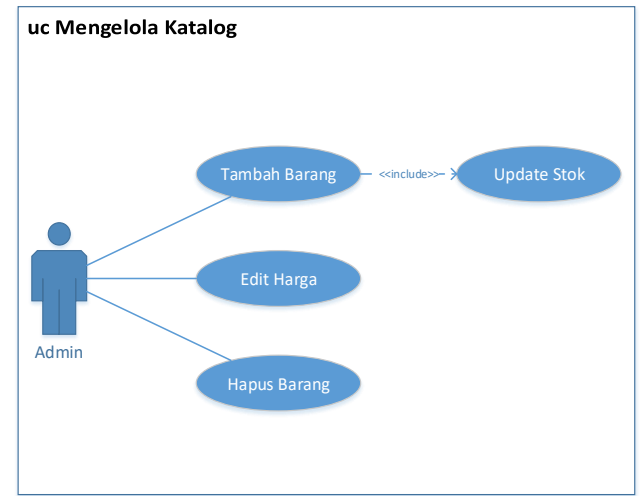

Gambar 2. Use Case Mengelola Katalog

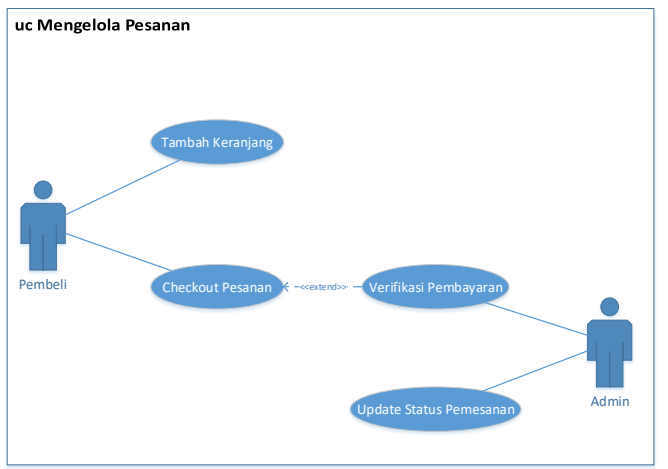

Gambar 3 : Use Case Mengelola Pesanan

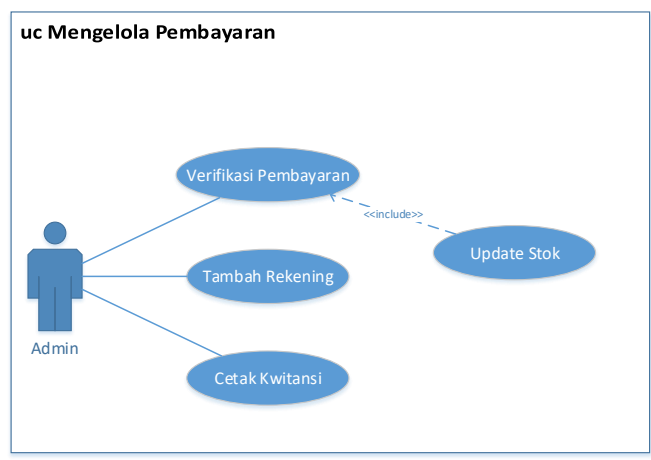

Gambar 4 : Use Case Mengelola Pembayaran

Adapun alur yang lebih rinci yaitu pembeli memesan barang yang ingin dibeli melalui aplikasi ini kemudian penjual akan meresponnya dan mempersiapkan barangnya, setelah barang yang dipesan 
siap maka penjual akan membawakan barang ke tempat pembeli yang sudah menentukan lokasi. Setelah barang sampai maka pembeli akan melakukan pembayaran ke penjual. Aplikasi ini akan dikelola oleh desa sehingga pembayaran sewa tempat dipasar akan melalui aplikasi ini, untuk lebih jelas proses pembelian melalui Rare Angon App sebagai berikut.

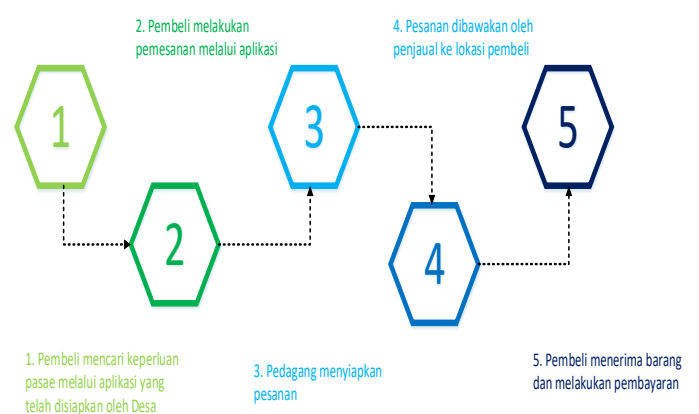

\section{Gambar 5 : Alur Rare Angon App}

Rare Angon App menggunakan aplikasi berbasis mobile dimana akan berjalan sesuai dengan alur diatas dengan bentuk design sebagai berikut.

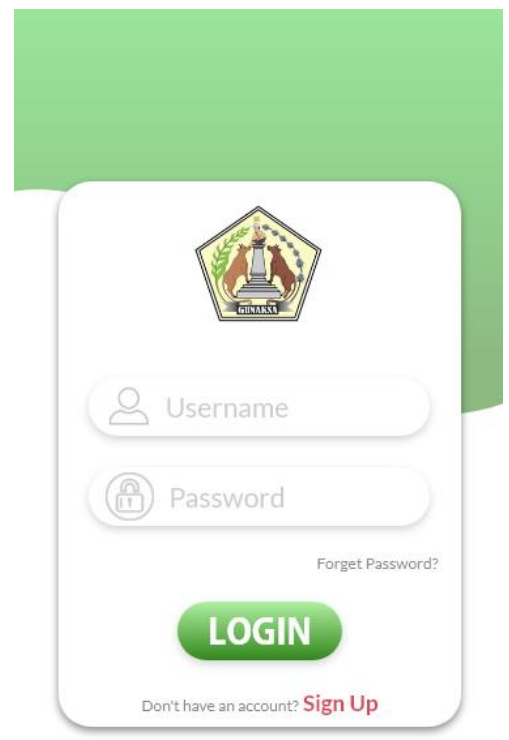

Gambar 6 : Page Login

\section{SIMPULAN}

Setelah dirancang dan dilakukan analisi pengabdian masyarakat ini munculah sebuah rancangan platform digitalisasi pasar dengan berjualan seperti ecommerce dengan menggunkan CMS (Content Management Systems) Wordpress yang sudah tersedia plugin WooCommerce untuk pembuatannya.Dengan adanya sebuah platform digitalisasi pasar ini diharapkan masyarakat dapat berbelanja di pasar Rare Angon dengan mudah tanpa harus datang ke pasar sehingga penularan covid19 bisa terhindari dan perekonomian di desa Gunaksa dapat pulih kembali.

\section{UCAPAN TERIMA KASIH}

Ucapkan terimakasih sebesarbesarnya kepada Rektor Universitas Pendidikan Nasional seta Dekan Fakultas Teknik dan Informatika Universitas Pendidikan Nasional Yang telah memberikan kesempatan dalam pelaksanaan PKM ini.

\section{DAFTAR PUSTAKA}

Ariyani, N. I., \& Nurcahyono, O. (2014). Digitalisasi Pasar Tradisional: Perspektif Teori Perubahan Sosial. Jurnal Analisa Sosiologi, 3(1), 1-12.

Arsyah, R. H., \& Juwita, A. I. (2021). Konvergensi Media dalam Pemasaran Produk Kerajinan Masyarakat desa Wisata Pariangan. Jurdimas (Jurnal Pengabdian Kepada Masyarakat) Royal, 4(1), 59-64. doi:10.33330/jurdimas.v4i1.948

Arta, D. (2021a). Pasar Rare Angon.

Arta, D. (2021b). Website Desa Gunaksa 
Available online at https://jurnal.stmikroyal.ac.id/index.php/jurdimas

klungkung.pdf.

Awan, S., Imam, S., \& Sumiyarsih, S. (2020). Digitalisasi Pasar Tradisional Di Masa Pandemi.

Bastian, A., \& Yusuf, Y. (2017). Fungsi Sosial Pasar Rakyat Bagi Masyarakat Desa Tasik Serai Barat Kecamatan Pinggir Kabupaten Bengkalis (Doctoral dissertation, Riau University).

Kotangon, F., Rares, J. J., \& Tampongangoy, D. (2018). Implementasi Kebijakan Pengelolaan Pasar Rakyat Kecamatan Pasan Di Kabupaten Minahasa Tenggara. Jurnal Administrasi Publik, 4(50).

Masyhuri, M., \& Utomo, S. W. (2017). Analisis Dampak Keberadaan Pasar Modern Terhadap Pasar Tradisional Sleko di Kota Madiun. Assets: Jurnal Akuntansi Dan Pendidikan, 6(1), 59. doi: 10.25273/jap.v6i1.1293

Putra, G. B., \& Atmaja, E. J. J. (2021). Pedampingan

Penggunaan
Sistem Informasi Profil Desa Banyuasin Berbasis Internet Dan Aplikasi Mobile. Jurdimas (Jurnal Pengabdian Kepada Masyarakat) Royal, 4(1), 97102.

doi:10.33330/jurdimas.v4i1.897

Santosa, A., Suharjo, I., \& Sumiyarsih. (2020). DIGITALISASI PASAR TRADISIONAL DI MASA PANDEMI. In Rizki Wahta Saputra (Ed.), MBridge Press (1st ed.). MBridge Press.

Sigalingging, E. D., \& Sitepu, J. (2020). Pengaruh costomer behavior dan e-commerce terhadap pasar modern di kota medan. JIMAT (Jurnal Ilmiah Mahasiswa Akuntansi), 11-21.

Sudirman, E. (2020). Strategi Usaha Kecil Menghadapi Digitalisasi Pemasaran. Jurnal Ilmu Manajemen, 9(2), 142. doi: 10.32502/jimn.v9i2.2554

Wirya, A. (2021). UPDATE STATUS COVID-19.pdf. 